International Journal of Advancement in Life Sciences Research
Online ISSN: $2581-4877$

Original Article

\title{
Potentials of Cuminum cyminum in Microbial Control
}

\author{
Debajyoti Bose \\ Professor, Department of Biological Sciences, Yobe State University, \\ Damaturu, Yobe State, Nigeria. \\ Correspondence E-mail: debajyotibose@gmail.com
}

\begin{abstract}
Cumin is one of the important spices known for their distinctive aroma, cumin seeds are sprinkled over popular North African, Middle East, Western, Chinese, Indian, Cuban and Northern Mexican cuisines. The spice is native to middle-east, Asian region, and now grown all over the world for its flavorful seeds. The plant is the small flowering herb belonging to the family of Apiaceae of the genus Cuminum, and scientifically known as Cuminum cyminum. It is an important condiment and spice crop grown in India for its aromatic-seed. India is the leading country in the world in production, consumption and export of cumin. It is grown in Madhya Pradesh, Rajasthan, Gujarat, West Bengal, Assam, Kerala, Uttar Pradesh and Punjab. Cumin is used as condiment for flavor and in medicines. Though cumin is one of the important spice crops with high economic returns, it has not yet gained commercial significance in most of the areas favorable for its cultivation. RS-I variety of cumin plant is recommended for Haryana, Punjab and Rajasthan. Cumin plays an important role in human health owing to their anti-inflammatory, anti-allergic, antimicrobial, anticarcinogenic, antiviral activities. Furthermore, it is anti-diuretic and anti-oxidant.

Considering the above facts our study was carried out to observe \& evaluate the effect of extracts from cumin against microbial population considering both bacterial \& fungal forms. Cumin-acetone fractions were extracted with Soxhlet and considered for tests against Gram negative bacteria (Escherichia coll), Gram-positive bacteria (Staphylococcus aureus) and the fungi (Aspergillus niger, Penicillium notatum, Mucor indicus). All the observations showed positive results by appearance of clear zone of inhibition on cultured petri plates for bacteria. However, Work on fungal species are on progress. Further, studies are going on MIC and analysis of the extract, which may provide us new ideas in the study of bio-active agents.
\end{abstract}

Keywords: Cuminum cyminum, acetone, bacteria, bio-active agents.

\section{Introduction}

Cumin (Cuminum cyminum) is a flowering plant, belonging to the family Apiaceae, is a herbaceous annual plant, with a slender branched stem $20-30 \mathrm{~cm}$ tall. The leaves are $5-10 \mathrm{~cm}$ long, pinnate or bipinnate, thread-like leaflets. The flowers are small, white or pink, and borne in umbels. The fruit is a lateral fusiform or ovoid achene 4-5 mm long, containing a single seed. In India cumin is known as 'jeera' or 'jira'. Cumin originates from Egypt, Turkistan and East Mediterranean, but it is cultivated in Iran, China, India, Morocco, south Russia, Japan, Indonesia, Algeria and Turkey (Tuncturk, R., \& Tuncturk, M., 2006). In Iranian folk medicine, cumin seeds have been used to treat diarrhea, toothache and epilepsy (Zargari, A., 1989). In recent years, there are some reports regarding the anti-diabetic 
activities (Talpur, et al., 2005) of this herb and its effects on reductions of cholesterol, phospholipids, free fatty acids, and triglycerides in plasma and tissue (Dhandapani, et al., 2002; Malini \& Vanithakumari, 1987). Chemical composition of cumin seed essential oil has been extensively studied (Behera et al., 2004; Hashemi et al., 2008) and cuminaldehyde has been introduced as the characteristic constituent of the seed (Sowbhagya, H. B. et al., 2008). Potentials of cuminaldehyde as a major agent for antidiuretic therapeutics were also reported (Lee H-S, 2005). Different studies have been conducted on the yield of cumin essential oil (Raghavan, 2007), the effect of size reduction and expansion on yield and quality of cumin seed oil was evaluated. For small batch size operations $(200 \mathrm{~g})$, oil yield was found to be the same (3.4\%) for both ground and flaked. Cumin also contains 10\% fixed oil (Nostro, et al., 2005). C. cyminum seeds are also used for treatment of dyspepsia and jaundice (Allahghadri, et al., 2010), whereas, essential oil of $C$. cyminum seed exhibits diuretic, carminative, emmenagogic, antibacterial, antioxidant, cytotoxic, and antispasmodic properties (Li \& Jiang, 2004). Cumin seed contains fixed oil (approximately $10 \%$ ), protein, cellulose, sugar, mineral elements and volatile oil (Peter, 2001). They also contain volatile oil (1-5\%) that accounts for the typical aroma of cumin seeds. The essential oil is responsible for the characteristic cumin odor. This odor and flavor are due principally to the aldehydes present. Studies of the chemical composition of cumin oil from different countries showed the presence of the following components: $\alpha$ pinene $(0.5 \%)$, Myrcene $(0.3 \%)$, limonene $(0.5 \%)$, 1 -8-cineole $(0.2 \%)$, p-menth-3-en-7-ol (0.7\%), pmentha-1, 3-dien-7-ol (5.6\%), caryophyllene $(0.8 \%), \beta$-bisabolene $(0.9 \%), \beta$ pinene $(13.0 \%), \quad$-cymene $(8.5 \%), \quad \beta$ phellandrene $(0.3 \%)$, D-terpinene $(29.5 \%)$, cuminic aldehyde (32.4\%), cuminyl alcohol $(2.8 \%), \quad \beta$-farnesene $(1.1 \%)$ together with much smaller quantities of $\alpha$ - phellandrene, $\alpha$ terpinene, cis and trans sabinene, Myrtenol, $\alpha$ terpineol and phellandral (Nanasombat, \& Lohasupthawee, 2005). A comprehensive and extensive study was done by Liu, Q. et al.
(2017) on several spices, such as clove, oregano, thyme, cinnamon, and cumin. Study results showed significant antimicrobial activities against food spoilage bacteria like $B$. subtilis and $P$. fluorescens; pathogens like $S$. aureus, $V$. parahaemolyticus, and $S$. typhimurium; harmful fungi like $A$. flavus and A. niger; and even antibiotic resistant microorganisms such as MRSA. Therefore, these spices could be used to decrease the possibility of food poisoning and spoilage, to increase the food safety and shelf-life of products, and to treat some infectious diseases. In another study cumin was discussed as the major antimicrobial component inhibiting growth of $B$. cereus, $B$. subtilis, Ls. monocytogenes, $C$. freundii, $K$. pneumoniae, Ps. fluorescens, S. enteritidis, St. aureus, A. niger, S. cerevisiae, C. albicans (Gottardi, et al., 2016). India represents the world leader in the jeera production. India's production sums up to 1 to 2 lakh tons of jeera per year that makes it the leading producer in the world. The country also has the largest area allotted towards jeera production i.e. around 5.25 lakh hectares. The level of production and the total area under jeera cultivation has increased significantly during the last few years. Rajasthan is the largest cumin producing state and Gujrat is second largest state in India.

Considering the above facts our study was carried out to observe \& evaluate the effect of extracts from cumin against microbial population considering both bacterial \& fungal forms. Cumin-acetone fractions were extracted with Soxhlet and considered for tests against Gram negative bacteria (Escherichia coli MIC 2642), Gram-positive bacteria (Staphylococcus aureus MIC 7443) and the fungi (Aspergillus niger NCIM 1054, Penicillium notatum NCIM 745, Mucor indicus MTCC 3318 and Trichoderma viride NCIM 1053). All observation showed positive results by appearance of clear zone of inhibition on cultured petri plates for bacteria. Moreover, Works on fungal species are on progress. Further, studies are going on MIC and analysis of the extract, which may provide us new ideas in the study of bio-active agents. 


\section{Materials and Methods}

\section{Plant materials}

The plants used in this study was Cuminum cyminum (common name: Cumin); the seed was collected from the local spice shops. After collection, $10 \mathrm{~g}$ of each of the plant parts were coarsely powdered using a mortar and pestle and were further reduced to powder using an electric blender. The powder was transferred into closed containers.

\section{Preparation of extracts}

\section{Soxhlet extraction:}

The dried and powdered plant materials $(10 \mathrm{~g})$ were extracted successively with $140 \mathrm{ml}$ and $190 \mathrm{ml}$ of the two concentration of solvents by using soxhlet extractor for $8 \mathrm{~h}$ at a temperature not exceeding the boiling point of the Solvent (Lin, et al., 1999). The concentration of solvents used for the study was $50 \%$ acetone and $100 \%$ acetone. The extracts were filtered and then concentrated to dryness. Each extract were transferred to glass vials and kept at $4^{\circ} \mathrm{C}$ before use.

\section{In vitro testing of extracts for antimicrobial activity:}

Antibacterial assay:

Overnight cultures of the Gram positive strains Staphylococcus aureus and the Gram negative strains Escherichia coli were prepared on nutrient agar plates. All bacterial isolates were suspended in saline to turbidity. Sterile molten nutrient agar at around $40^{\circ} \mathrm{C}$ was taken and seeded with different bacterial

\section{Results}

Soxhlet extraction:

Yield of the extract obtained was calculated as follows:

Table 1. Yield of the extract

\begin{tabular}{|c|c|c|}
\hline SAMPLE & SOLVENT & YIELD \\
\hline \multirow{2}{*}{ Cumin } & Acetone (50\%) & $7.28 \%$ \\
\cline { 2 - 3 } & Acetone (100\%) & $10.5 \%$ \\
\hline
\end{tabular}

cultures and plates were prepared. After solidification $4 \mathrm{~mm}$ wells were prepared. In these wells solvent extracts of the peel were added. The plate was incubated overnight at $37^{\circ} \mathrm{C}$. After incubation the zones of inhibition were measured and recorded. Respective solvent controls were also run simultaneously.

\section{Antifungal Assay:}

Cultures of fungal strains Penicillium notatum, Trichoderma viridae, Aspergillus niger and Mucor indicus were prepared on Potato Dextrose agar plates. All fungal isolates were suspended to turbidity. Sterile molten agar plates was taken and seeded with different fungal cultures and plates were prepared. After solidification $4 \mathrm{~mm}$ wells were prepared. In these wells solvent extracts of the spice were added. The plate was incubated overnight at $27^{\circ} \mathrm{C}$. After incubation the zones of inhibition were measured and recorded. Respective solvent controls were also run simultaneously.

\section{Conformity Test with Nutrient Broth:}

The extract was diluted up to $1: 100$ concentration and three test tubes were prepared:

1) Extract+Nutreint Broth+Bacterial Colony

2) Extract+Nutrient Broth

3) Nutrient Broth+Bacterial Colony

After preparation of the test tubes the samples were kept for $24 \mathrm{hrs}$ incubation. Absorbance at $540 \mathrm{~nm}$ was measured and the growth in each test tube was compared.

\section{Antibacterial Activity:}

Antibacterial activity for the sample Cumin is as follows:

Table 2. Zone of inhibition of the extract showing antibacterial activity

\begin{tabular}{|l|c|l|}
\hline BACTERIA & SOLVENT & $\begin{array}{l}\text { ZONE OF } \\
\text { INHIBITION }\end{array}$ \\
\hline Escherichia coli & Acetone $(50 \%)$ & $10 \mathrm{~mm}$ \\
\hline & Acetone $(100 \%)$ & $15 \mathrm{~mm}$ \\
\hline $\begin{array}{l}\text { Staphylococcus } \\
\text { aureaus }\end{array}$ & Acetone $(50 \%)$ & $12 \mathrm{~mm}$ \\
\hline & Acetone $(100 \%)$ & $16 \mathrm{~mm}$ \\
\hline
\end{tabular}


Antifungal Activity:

The antifungal activity of Cumin is as follows:

Table 3. Zone of Inhibition showing antifungal activity

\begin{tabular}{|c|l|c|}
\hline FUNGUS & \multicolumn{1}{|c|}{ SOLVENT } & ZONE OF INHIBITION \\
\hline \multirow{2}{*}{ Aspergillus niger } & Acetone $(50 \%)$ & No zone \\
\cline { 2 - 3 } & Acetone $(100 \%)$ & No zone \\
\hline Penicillium notatum & Acetone $(50 \%)$ & No zone \\
\hline \multirow{3}{*}{ Trichoderma viride } & Acetone $(100 \%)$ & No zone \\
\hline \multirow{2}{*}{ Mucor indicus } & Acetone $(50 \%)$ & No zone \\
\cline { 2 - 3 } & Acetone $(100 \%)$ & No zone \\
\hline & Acetone $(50 \%)$ & No zone \\
\cline { 2 - 3 } & Acetone $(100 \%)$ & No zone \\
\hline
\end{tabular}

\section{Confirmatory Test for bacteria}

Table 4. Confirmatory test using Nutrient Broth

\begin{tabular}{|c|c|c|c|c|c|}
\hline \multirow{2}{*}{ BACTERIA } & SOLVENT & \multicolumn{3}{|c|}{ ABSORBANCE } \\
\cline { 3 - 6 } & & $\mathbf{A}$ & $\mathbf{S}$ & $\mathbf{X}$ & C \\
\hline Escherichia coli & Acetone (50\%) & 0.31 & 0.29 & 0.03 & 0.46 \\
\hline
\end{tabular}

Where A stands for All contains sample, nutrient broth and E.coli; S for nutrient broth and sample; X is A-S and C for control (Nutrient broth \& E.coli).

\section{Discussion}

The overall evaluation of this study shows that the cumin extract has a good antimicrobial potential. The volatile components of the extract of spices showed appreciable amounts of antibacterial activity against Gram positive bacteria, Gram negative bacteria with prominent zone of inhibition. 100\% acetone extracts were found to have better antimicrobial action than any other solvents like ethanol, nhexane, $50 \%$ acetone extracts. So this study concludes that cumin have good antioxidant potential and this spices can be used to produce novel natural antioxidants as well as flavoring agents that can be used in various food products. The oils of cumin seed extract showed greater antibacterial activity against all strains tested, with a prominent zone of inhibition. Especially for E.coli, the extract showed maximum result which is similar to the result reported by Nanasombat \& Lohasupthawee (2005). The concentration of extracting solvent significantly affected contents of cumin seeds extract. The optimal extraction solvent yielding the highest content of non-volatile components in cumin extract is
$100 \%$ acetone which is also similar to result reported by Bettaieb et al. (2010).

\section{Conclusion}

Cumin seed extract can be utilized as an antibacterial agent to kill gram positive \& gram negative bacteria such as Staphylococcus aureus and Escherichia coli in-vitro. Further investigations on identification and separation of antimicrobial components (chemicals) from cumin seed will be done along with efficiency testing. Comparative studies will be carried out on different fungal species using different extraction methods with different solvents. This type of study will lead us to advancement of medical sciences along with a complete knowledge on naturally occurring antimicrobial components from cumin seed \& their applications.

\section{Acknowledgement}

Author highly acknowledges Yobe State University, Damaturu, Yobe State, Nigeria for providing moral support for this research work. 


\section{References}

Allahghadri, T., Rasooli, I., Owlia, P., Nadooshan, M. J., Ghazanfari, T. \& Taghizadeh, M. (2010). Antimicrobial property, antioxidant capacity, and cytotoxicity of essential oil from cumin produced in Iran. Journal of Food Science, 75, 54-61.

Behera, S., Nagarajan, S. \& Jagan Mohan Rao, L. (2004). Microwave heating and conventional roasting of cumin seeds (Cuminum cyminum L.) and effect on chemical composition of volatiles. Food Chemistry, 87, 25-29.

Bettaieb, I., Bourgou, S., Wannes,W. A., Hamrouni, I., Limam, F. \& Marzouk, B. (2010). Essential Oils, Phenolics, and Antioxidant Activities of Different Parts of Cumin (Cuminum cyminum L.). Journal of Agriculture and Food Chemistry, 58(19), 10410-10418.

Dhandapani, S., Subramanian, V. R., Rajagopal, S. \& Namasivayam, N. (2002). Hypolipidemic effect of Cuminum cyminum L. on alloxan - induced diabetic rats. Pharmacological Research, 46(3), 251-255.

Gottardi, D., Bukvicki, D., Prasad, S. \& Tyagi, A.K.(2016). Beneficial Effects of Spices in Food Preservation and Safety. Frontiers in Microbiology, 7, 1394. doi:10.3389/fmicb. 2016. 01394.

Hashemi, P., Yarahmadi, A., Azizi, K. \& Sabouri, B. (2008). Study of the effects of $N$ fertilization and plant density on the essential oil composition and yield of Cuminum cyminum L. seeds by HS-SME. Chromatographia, 67, 253-257.

Lee, H-S. (2005). Cuminaldehyde: Aldose reductase and alpha-glucosidase inhibitor derived from Cuminum cyminum L. seeds. Journal of Agriculture and Food Chemistry, 53, 2446-2450.

Li, R., \& Jiang, Z. T. (2004). Chemical composition of the essential oil composition (Cuminum cyminum L.) from China. Flavour and Fragrance Journal, 19, 311-313.

Lin, J.G., Arunkumar, R. \& Liu, C.H. (1999). Efficiency of supercritical fluid extraction for determining 4-nonylphenol in municipal sewage sludge. Journal of Chromatography $A$, 840,71-79.

Liu, Q., Meng, X., Li,Y., Zhao, C-N., Tang, G-Y. \& Li, H-B. (2017). Antibacterial and Antifungal Activities of Spices. International Journal of Molecular Sciences, 18, 1283. doi:10.3390/ ijms18061283.

Malini, T. \& Vanithakumari, G. (1987). Estrogenic activity of Cuminum cyminum in rats. Indian Journal of Experimental Biology, 5, 442-444.

Nanasombat, S. and Lohasupthawee, P. (2005). Antibacterial activity of crude ethanolic extract and essentials oils of spices against salmonellae and other enterobacteria. KMITL Science and Technology Journal, 5(3), 527538.

Nostro, A., Cellini, L., Di Bartolomeo, S., Di Campli, E., Grande, R., and Cannatelli, M. A. (2005). Antibacterial effect of plant extracts against Helicobacter pylori. Phytotherapy Research, 19(3), 198-202.

Peter, K. V. (2001). Handbook of herbs and spices, Vol. 1, Woodhead Publishing Limited Abington Hall, Abington Cambridge, England.

Raghavan, S. (2007). Handbook of spices, seasonings, and flavorings. 2nd Ed. CRC Press, Taylor \& Francis Group, Boca Raton, USA.

Sowbhagya, H. B., Rao, B. V. S. \& Krishnamurthy, N. (2008). Evaluation of size reduction and expansion on yield and quality of cumin (Cuminum cyminum) seed oil. Journal of Food Engineering, 84, 595-600.

Talpur, N., Echard, B., Ingram, C., Bagchi, D. \& Preuss, H. (2005). Effects of a novel formulation of essential oils on glucose-insulin metabolism in diabetic and hypertensive rats: a pilot study. Diabetes, Obesity and Metabolism, 7, 193-199.

Tuncturk, R. \& Tuncturk, M. (2006). Effects of different phosphorus levels on the yield and quality components of cumin (Cuminum cyminum L.). Research Journal of Agriculture and Biological Sciences, 2, 336-340.

Zargari, A. (1989). Medicinal plants, Vol II, Tehran University Press, Tehran, 519-521. 